\title{
The Emerging Trend of the Flipped Classroom: A Content Analysis of Published Articles between 2010 and 2015
}

\section{La tendencia emergente aula invertida: Un análisis de contenidos de los artículos publicados entre 2010 y 2015}

\author{
Hüseyin Uzunboylu \\ Near East University, Nicosia, Cyprus \\ huseyin.uzunboylu@gmail.com \\ Damla Karagözlü \\ Near East University, Nicosia, Cyprus \\ damla.karagozlu@gmail.com
}

\begin{abstract}
The concept of the flipped classroom is a recent technological innovation in the educational environment that shows much promise. The flipped classroom is a learning model where direct instruction is replaced by videos and in the actual classrooms, students are encouraged to focus on important learning activities with their teachers instead. Many studies have been carried out regarding the use of the flipped classroom in different subjects. The purpose of this study is to indicate the flipped classroom study trends over the past five years. A total of 65 articles were analyzed as part of this study and the reporting of the study was grouped according to the following criteria: year of publication, research country, sample group, research method, subject area, research model and data collection tool. As a result of this study, it was found that the number of publications on flipped classrooms has increased year over year. The flipped classroom approach has been applied to 48 different subject areas and the qualitative research method was mostly used. This research aims to guide all researchers who are working with flipped classrooms.
\end{abstract}

Key words: Flipped Classroom, Inverted Classroom, Blended Learning

\section{Resumen}

El concepto del aula invertida o volteada es una reciente innovación tecnológica en el entorno educativo que muestra muchas promesas. El aula volteada es un modelo de aprendizaje donde la instrucción directa es reemplazada por videos y en las aulas reales, se anima a los estudiantes a enfocarse en actividades de aprendizaje importantes con sus maestros en su lugar. Se han llevado a cabo muchos estudios sobre el uso del aula volteada en diferentes materias. El propósito de este estudio es indicar las tendencias de los estudios en el aula en los últimos cinco años. Se analizaron 65 artículos como parte de este estudio y el reporte del estudio se agruparon de acuerdo con los siguientes criterios; Año de publicación, país de investigación, grupo de muestra, método de investigación, área temática, modelo de investigación y herramienta de recopilación de datos. Como resultado de este estudio, se encontró que el número de publicaciones en aulas volteadas había aumentado año a año. El enfoque de aula invertida se ha aplicado a 48 áreas temáticas diferentes y el método de investigación cualitativa se utilizó principalmente. Esta investigación tiene como objetivo guiar a todos los investigadores que trabajan con aulas volteadas.

Palabras clave: aula volteada, aula invertida, aprendizaje combinado 


\section{Introduction}

Internet-based technologies and applications have become more and more prominent in many parts of our lives. While some of these technologies do not vary from paper resources, most of them provide unique opportunities for today's learners by incorporating more interactive features (Avci et. al, 2014). A flipped classroom is a learning approach that moves traditional lectures outside of the classroom setting and brings take-home activities such as discussions, case studies and simulation experiences into the classroom. As a result, active learning is achieved during the classroom time through the facilitation of the teacher (See and Conry, 2014). Students can watch video lessons online at their own homes and use class-time to carry out activities (Roach, 2014). In applications where interactive content and visuals are more forepart, students take more significant role in the learning-teaching process, as opposed to traditional learning environments (Ozdamlı and Tavukcu, 2016; Ozdamli and Asiksoy, 2016).

According to Bergmann et al. (2015), the definition of a flipped classroom is the replacement of direct instruction with video lessons and the encouragement of students to focus on important learning activities with their teachers inside the classroom. Although there is an information gap concerning the flipped classroom, it can be clarified as a personalised education where students take responsibility of their own learning. In addition, the flipped classroom allows the teacher to be a facilitator and also increases the interaction and personal contact time between teacher and student. The flipped classroom is also explained as the establishment of problem-based learning inside the class by replacing direct instruction with video lessons in order to provide instructional content that can be accessed by students whenever and wherever it is required (Bergmann and Sams, 2012; Hamdan et. al., 2013). Hamdan et. al. (2013) stated that instruction can be delivered by recording narrated screencasts of work electronically, by creating videos of teachers giving lessons or by gathering video lessons from trusted internet sites.

The flipped classroom model has existed for some time, under different guises. Salman Khan garnered considerable attention with the development of the Khan Academy, where over 4400 instructional videos were recorded and stored in its digital library for the purpose of covering K-12 level mathematics, history, science and various subjects (Chen et. al, 2014). Many instructors benefited from the opportunity of using these 10 minute long videos while practicing the flipped model in their classes. The course videos were watched by students at home and other activities such as homework were done in school. Bergmann and Sams (2012) supposed that the terms "blended learning," "reverse instruction," "inverted classroom," and "24/7 classroom" have the same meaning. In contrast, Staker and Horn (2012) stated that the flipped classroom is not the same method as blended learning; it is actually a sub-model of blended learning. Blended learning was separated into four operational models which are the "Rotation model," the "Flex model," the "Self-Blend model," and the "Enriched-Virtual model" by Staker and Horn (2012). In the Rotation-model, students attend class where they can benefit from various sizes of group projects, assignments and tutorials. One of the submodels of the Rotation-model is flipped classroom which supports students to watch instructional videos before the class activities.

A previous academic survey showed that there are synonymous terms with flipped teaching that have been used in other studies (Hung, 2015). The term 'inverted 
classroom' is used by Lage and Platt (2000), 'Just - In - Time Teaching' (JiTT) is used by Novak (2011), 'flipped classroom' is used by Bergmann and Sams (2012) and 'inverted learning' is used by Barker et al. (2013) as terms to explain the same approach.

Planning and responsibility are two requirements of a successful flipped classroom. Content spread can be prevented and student implementation regarding learned activities can be supported by the use of the flipped classroom model. Furthermore, all levels of Bloom's Taxonomy can be achieved using this model. The outside classroom content are relevant to the lower levels of Bloom's Taxonomy such as understanding and remembering while the inside classroom content corresponds with the higher order levels such as creating, evaluating, analyzing and applying (See and Conry, 2014). Design principles for the flipped classroom are recommended by Kim et. al. (2014) as the following:

- Providing the opportunity for students to gain preliminary information before the class activity,

- Encouraging students to watch online lectures and be prepared before the class activity,

- Organizing methods of assessment,

- Linking in-class activities with out-of-class activities,

- Supplying clearly stated and well organized guidance,

- Providing sufficient time for the completion of assignments,

- Promoting students to build a learning community,

- Providing immediate feedback on individual or group work,

- Providing the use of familiar technologies that can be easily accessed by students.

There are obvious advantages to the flipped learning approach; the learning environment is not just limited to the classroom, subject learning can occur at the students' home and at their own pace, students can work on problems in the classroom with the instructor, there is more one-on-one time with teachers and students can catchup on missed lectures. (Mate and Salinas, 2014; Roach, 2014).

According to Roach (2014), there are also potential drawbacks to flipped learning; limited access to an internet connection and appropriate technology or increased reliance on lecturing in the videos would revert the lecturing style back to a normal classroom.

\section{Literature Review}

Studies conducted on flipped classroom applications in education in recent years in the literature are summarized in this section.

See and Conry (2014) provided a unique flipped classroom model for a clinical pharmacy practice faculty. The faculty instructors were required to watch a YouTube origami video on "How to make a paper crane" along with a Prezi presentation. They were then asked to build their own crane and send a picture of it to the facilitators by the set deadline. In-class activities included a quiz on the homework, evaluation and feedback of the cranes provided by faculty instructors along with individual, small and large group reflections. This study was successful in sensitizing faculty to the flipped classroom approach, which means that this faculty development program could be a 
model for other educational institutions to modify their teaching techniques when teaching pharmacy students.

Roach (2014) implemented a partly-flipped class during a semester for microeconomics course and analyzed students' perceptions toward the flipped learning method. At the end of the course it was found that students had a positive impression of the flipped classroom.

Baepler et. al. (2014) applied the flipped classroom model to a chemistry class and investigated the effect of decreasing the time students spent seated inside a traditional amphitheater. The findings of the study showed that the learning outcomes achieved by students were at least as good as in the traditional classroom.

Butt (2014) studied a flipped classroom approach by inverting classroom materials with after-class materials for a final-year actuarial course. Student views for the structure of flipped classroom were obtained at the start and end of the semester. At the end of the study, it was found that there was a significantly positive change in student perceptions of the flipped classroom approach.

Love et al (2014) applied a flipped classroom model for a section of an applied linear algebra course and a traditional lecture format for another section of the course. End of semester survey and exams were organized for the examination of student content understanding and course perceptions. Sequential exams showed that students in the flipped classroom had more understanding of subject than students who were in the traditional lecture section. In addition, the results from the end of semester survey showed that flipped classroom students were quite positive regarding the course.

Gilboy et. al. (2015) implemented the flipped classroom model in two undergraduate nutrition courses and assessed the student perceptions regarding the model. The template allows faculty members to design activities that can take place before, during and after the class and also assessments taking into consideration Bloom's Taxonomy. It was found that the majority of the 142 students in the courses preferred the flipped method compared with the traditional classroom.

McLaughlin and Rhoney (2015) examined a flipped neurologic pharmacotherapy course's student performance, engagement and perceptions regarding an interactive online tool and compared the outcomes using the tool with the traditional downloadable paper handout. It was found that students who were using the online tool achieved considerably higher marks in their final exam.

Simpson and Richards (2015) used a flipped classroom approach to re-design a population health course for a nursing program. As a result, student reflections showed that students had a better understanding of the nursing curriculum content.

Hung (2015) investigated the effect of flipped classroom on academic achievement, learning attitudes and participation levels of English language learners. Three different formats of flipped teaching were applied and it was found that the structured and semistructured flipped lessons became more effective than the non-flipped lessons.

O'Flaherty and Phillips (2015) worked on a scoping review with the aim of providing a wide overview of studies which concern the emergence of the flipped classroom, the relationship among flipped classroom with pedagogy and educational outcomes and consequently show information deficiency in academic literature. The study was carried 
out with the use of Arksey and O'Malley's five-stage framework. As a result, 28 articles carried out in 5 different countries were included in the scope of the review. The analysis of the articles revealed that there is considerable indirect evidence emerging that shows improved academic performance and student/staff satisfaction with the flipped approach. On the other hand, there is a lack of conclusive evidence concerning the contributions of the flipped classroom to the development of lifelong learning and other 21 st century skills in undergraduate and post-graduate education.

Looking at examples within the previous publications, it was found that the flipped classroom model had been applied to various educational disciplines with the aim of increasing interaction and personalized contact time between students and instructors in the classroom setting. As seen in the studies in literature although scoping review study was carried out, no studies were found on the trends in publications concerned with the flipped classroom concept.

The aim of this study is to determine the trends in publications taken from the Science Direct database concerned with the flipped classroom concept during the period between 2010 and 2015.

\section{Methodology}

Quantitative content analysis was performed on the ScienceDirect database to generate findings from articles published on the subject of the flipped classroom between 2010 and 2015. The research was carried out using the keywords "Flipped Classroom" and the criteria for the content analysis originated from previous content analysis studies in academic publications. Content analysis studies by Keser et. al. (2011), Ozcinar (2009) and Drysdale et. al. (2013) lead this study for the selection of criteria. The criteria taken into account for the content analysis are: publication year, country where the research was implemented, sample group, research method, subject area, research model and data collection tools. In order to achieve the aim of this study, the following seven research questions were determined:

- What is the number of publications by year of study?

- What is the number of publications according to country?

- What is the distribution of studies in terms of sample groups?

- What are the research methods used in the studies?

- What are the subject areas of the studies?

- What are the research models used in the studies?

- What are the data collections tools used in the studies?

For the data analysis, all data was gathered from the articles using the above criteria and coded in the SPSS package program. Data frequencies were taken by using filter characteristics from the SPSS software.

\section{Results}

A total of 242 studies were returned as a result of the scan of the ScienceDirect database for the years 2010 to 2015 . However, complete text was not provided by the database for 15 of the articles. Therefore, 227 articles were analyzed and 15 articles were disregarded for the purposes of this study. Results were achieved related to the selected criteria and are indicated by the following graphs and tables. 


\section{Distribution of Articles According to Publication Years}

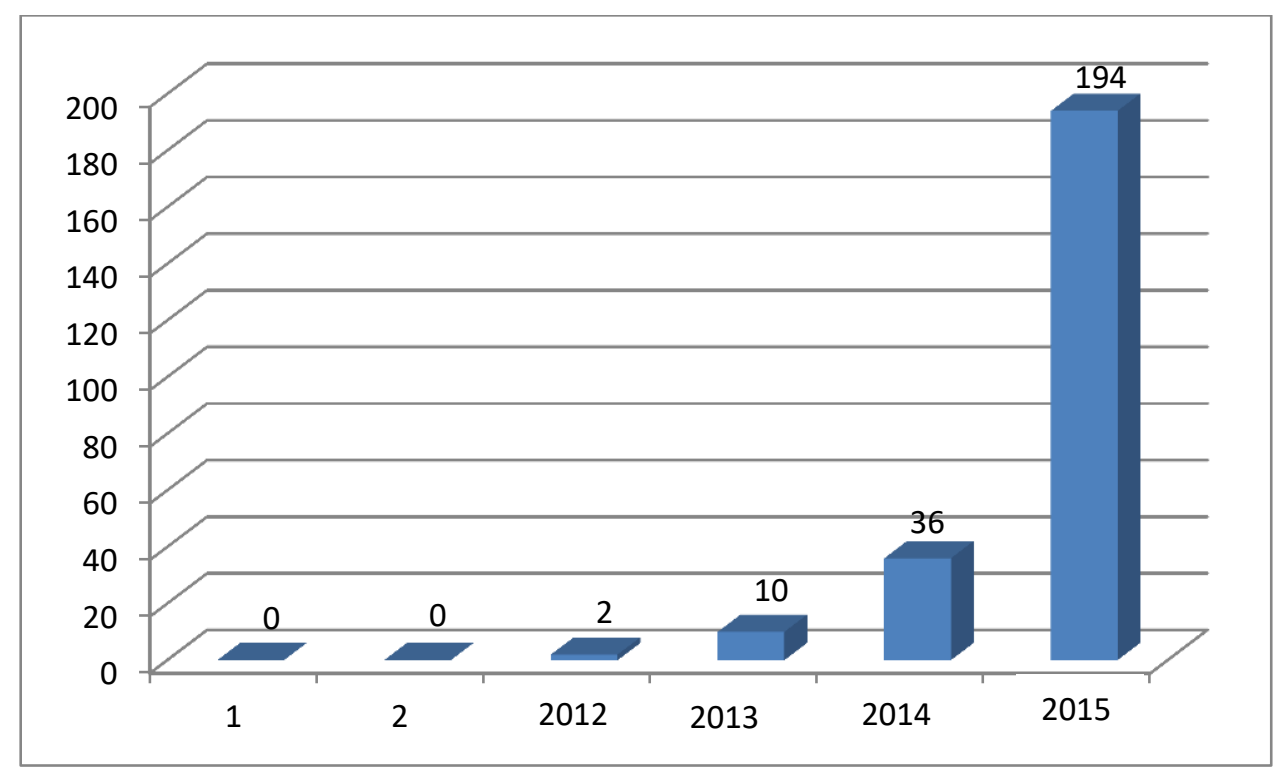

Figure 1: Number of Articles According To Publication Year

Figure 1 demonstrates the number of articles according to their publication year. The highest number of publications on flipped classroom was in 2015 (194) and there were no publications in 2010 or 2011 . The number of publications in 2012 was 2, 10 in 2013 10 and, 36 in 2014.

\section{Distribution of Articles According to Countries}

\begin{tabular}{ll}
\hline Countries & Frequency \\
\hline USA & 163 \\
Malaysia & 10 \\
Jamaica & 10 \\
Hong Kong & 4 \\
Singapore & 4 \\
Spain & 4 \\
Somaliland & 4 \\
Netherlands & 4 \\
Switzerland & 4 \\
China & 3 \\
Sweden & 3 \\
Taiwan & 3 \\
Australia & 3 \\
Finland & 2 \\
Canada & 2 \\
\end{tabular}

The Emerging Trend of the Flipped Classroom: A Content Analysis of Published Articles between 2010 and 2015. Hüseyin Uzunboylu y Damla Karagözlü 


\begin{tabular}{lc} 
UK & 2 \\
Norway & 2 \\
\hline Table 1: Number of Articles According To Country
\end{tabular}

Table 1 shows the distribution of articles by the country of implementation. There were 17 countries in total where research was conducted in the scope of the ScienceDirect database. As can be seen in the table, there is a remarkable difference between the number of studies that took place in the USA compared with all other countries. As many as 163 publications on the flipped classroom were conducted in the USA; 10 publications were carried out in Malaysia and Jamaica; 4 publications in Hong Kong, Singapore, Spain, Somaliland, Netherlands and Switzerland; 3 publications in China, Sweden, Taiwan, Australia and 2 publications were conducted in Finland, Canada, UK and Norway respectively.

The Sample Groups of Reviewed Studies

\begin{tabular}{lc}
\hline Sample Groups & Frequency \\
\hline Undergraduate Students & 119 \\
Community Educators & 21 \\
Children & 16 \\
Teachers & 16 \\
Academicians & 13 \\
Graduate Students & 13 \\
Secondary School Students & 13 \\
Middle School Students & 8 \\
Residents & 8 \\
\hline Table 2: Sample Groups of Reviewed Articles
\end{tabular}

The preferred sample groups in the analyzed publications are indicated by Table 2 . Undergraduate students were the most preferred sample group in the analyzed articles with a frequency of 119. Community educators took part in 21 research studies. Children and Teachers were the sample group of 16 studies. Academicians, graduate students and secondary school students were the sample group for 13 publications, residents and middle school students took part in 8 research studies as a sample group.

Research Methods of the Reviewed Studies 


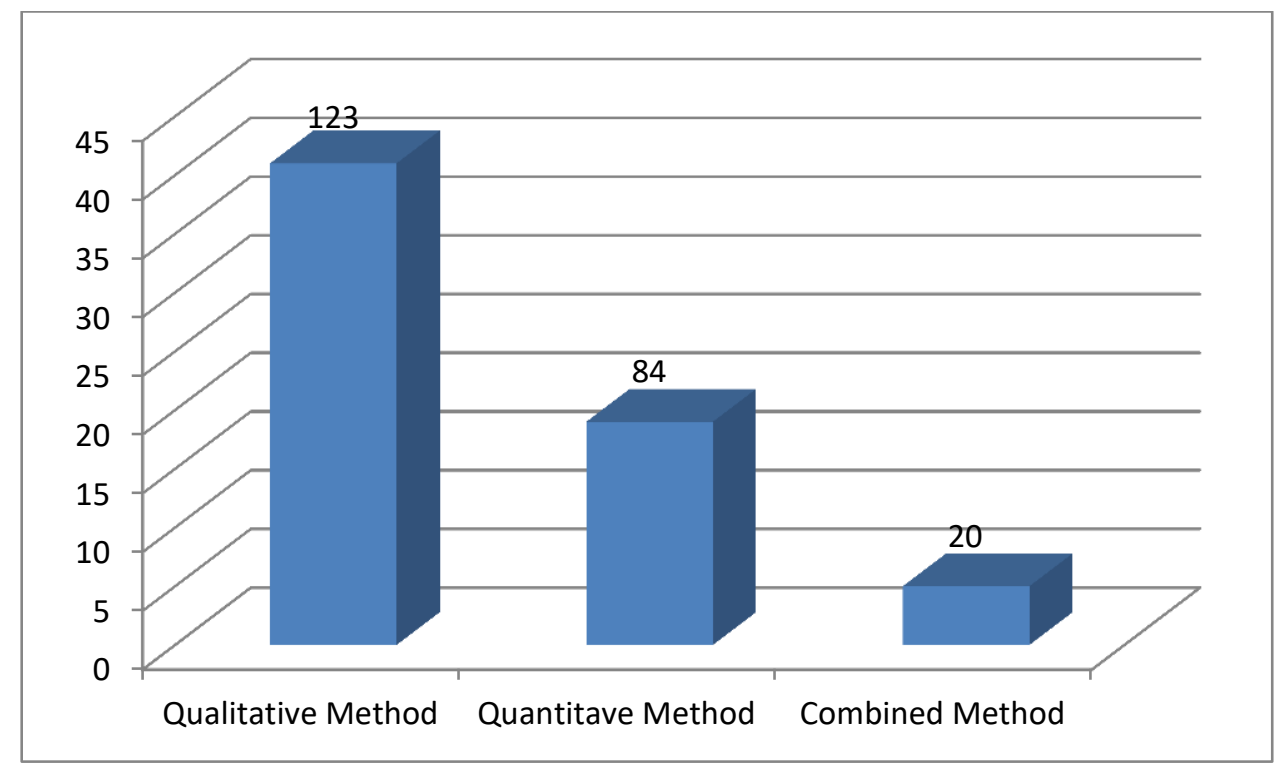

Figure 2: Number of Articles According To Research Methods

Figure 2 displays the number of articles according to their research methods. As can be seen in the chart, 123 of the analyzed studies were carried out using the qualitative research method, 84 studies were performed using the quantitative research method and 20 studies combined both research methods for their data gathering.

\section{Distribution of Articles According to Subject Areas}

\begin{tabular}{ll|ll}
\hline Subject Areas & Frequency & Subject Areas & Frequency \\
\hline Medical Education & 68 & Business Management & 7 \\
Nursing & 21 & Humanities & 7 \\
Pharmacy & 17 & Nutrition & 7 \\
Computer Science & 17 & Librarianship & 3 \\
Science & 17 & Arts & 3 \\
Mathematics & 14 & General Education & 3 \\
Psychology & 14 & Special Education & 3 \\
Language Education & 10 & Sport and Recreation & 3 \\
& & Management & 3 \\
\hline
\end{tabular}

Table 3: Number of Articles According to their Subject Area

As shown in Table 3, the flipped classroom approach has been applied by studies in 18 different subject areas between 2010 and 2015. Medical Education was the most popular subject for the implementation of the flipped classroom with a frequency of 68 . There were also: 21 publications on Nursing; 17 publications on Pharmacy, Computer Science and Science; 14 publications on Mathematics and Psychology; 2 publications on Language Education and Engineering and 7 publications on Business Management, Humanities and Nutrition. The rest of the 6 various subject areas had 3 publications related to the flipped classroom approach.

Research Models of the Reviewed Studies

\begin{tabular}{llllll}
\hline Research Methods & $\mathbf{2 0 1 2}$ & $\mathbf{2 0 1 3}$ & $\mathbf{2 0 1 4}$ & $\mathbf{2 0 1 5}$ & Total \\
\hline Experimental & 0 & 4 & 14 & 55 & 73 \\
Case Study & 0 & 1 & 7 & 64 & 72
\end{tabular}

The Emerging Trend of the Flipped Classroom: A Content Analysis of Published Articles between 2010 and 2015. Hüseyin Uzunboylu y Damla Karagözlü 


\begin{tabular}{llllll}
\hline Descriptive & 1 & 2 & 4 & 33 & 40 \\
Review & 1 & 2 & 3 & 28 & 34 \\
Design Based & 0 & 0 & 2 & 6 & 8 \\
\hline
\end{tabular}

Table 4: Annual Distribution of Preferred Research Models

The annual distribution of preferred research models of the analyzed articles is displayed in Table 4. There were not any research studies on flipped classrooms between 2010 and 2011, therefore these years are not included in the table. It is indicated that although the experimental study model was not used until 2013, it was still the most popular research model over the last 3 years on the flipped classroom approach. Some 73 studies fell into the category of experimental study, whereas the number of studies carried out with a design-based model within the past 5 years was only 8 .

Data Collection Tools of the Reviewed Studies

\begin{tabular}{llllll}
\hline Data Collection Tools & $\mathbf{2 0 1 2}$ & $\mathbf{2 0 1 3}$ & $\mathbf{2 0 1 4}$ & $\mathbf{2 0 1 5}$ & Total \\
\hline Interviews & 1 & 3 & 7 & 11 & 22 \\
Achievement Tests & 0 & 1 & 7 & 35 & 43 \\
Questionnaire & 0 & 1 & 1 & 4 & 6 \\
Observation & 0 & 0 & 2 & 4 & 6 \\
Pre-Test \& Post-Test & 0 & 4 & 8 & 5 & 17 \\
Surveys & 0 & 0 & 7 & 40 & 47 \\
Documents & 1 & 0 & 3 & 33 & 37 \\
$\begin{array}{l}\text { Alternative Tools } \\
\text { (Portfolio, Discussion }\end{array}$ & 0 & 2 & 7 & 33 & 42 \\
Forum, Exercise...) & & & & & \\
\multicolumn{2}{c}{ Table 5: The Annual Distribution of Preferred Data Collection Tools }
\end{tabular}

Table 5 shows that surveys, achievement tests and alternative tools such as discussion forums, exercises etc. were the most used tools for data collection purposes over the past 5 years. Documents were applied in 37 and interviews were also applied in 22 of the studies concerning flipped classrooms. It also can be seen that the questionnaire and observation methods were not preferred in many studies for gathering data on flipped classrooms. There were not any research studies on flipped classrooms between 2010 and 2011, therefore these years are not represented in the table.

\section{Discussion and Conclusion}

The flipped classroom model "flips" in-class lectures with take-home activities. In a flipped classroom model, students watch recorded video lessons at home, understand the subject matter and do their homework exercises in the classroom with the facilitation of the instructor (Chen et. al, 2014). The learning environment has recently transformed as a result of the introduction into our lives of computers, the internet and other educational technologies. The flipped learning approach enhances these changes to our learning environments whereby the comprehension of a new topic can take place at home. These changes must be followed by each individual who has a role in 
education, such as academicians, teachers, researchers and students. This study is carried out in respect of meeting the mentioned needs. 242 flipped classroom studies were retrieved as a result of scanning the ScienceDirect database for relevant studies that were carried out over the past five years. Complete texts for 15 of the studies did not exist in the scanned database, therefore this study was carried out using a final total of 227 studies. Using this research, the aim was to guide further investigations into the subject of the flipped classroom.

Flipped learning is a learning design that plays a significant role in blended learning. Although blended learning is not a new approach, the flipped classroom model has emerged over the last few years. Researchers started to pay more attention to flipped classroom applications from 2012 onwards. The number of studies rapidly increased year after year, with the number of studies in 2015 promising a higher number of studies for the future.

This study revealed that $72 \%$ of the analyzed publications took place in the USA. O'Flaherty and Phillips (2015) also found that $82 \%$ of the articles that were analyzed in the scope of their study took place in the USA. This proportion shows that researchers in the USA are significantly more willing to work on a new subject or innovation. In addition, the flipped classroom has been researched in 17 different countries over the last 3 years, suggesting that the flipped classroom model appears highly likely to become widespread in the education environment in a short period of time. As with the study of O'Flaherty and Phillips (2015), this study also demonstrates that there is a remarkable absence of academic studies regarding the flipped classroom approach from European countries.

Students themselves were consulted for data collection in $67 \%$ of the studies that were reviewed. In addition, the most preferred research level was at universities as $52 \%$ of publications implemented the flipped classroom approach by including undergraduate students. The reason that undergraduate students were selected by the researchers could be due to the technological literacy requirement of the flipped classroom approach. Computers, the internet and certain software must be used by learners in order to complete the course. Therefore, the limited number of studies using younger students indicates that there is a need for further investigation in this particular subject area. Butt (2014) also revealed the deficiency in academic research concerning student perceptions and the effectiveness of a flipped classroom.

This study also exhibits the research method trends of researchers over the last 5 years. There are obvious differences among the number of studies performed using qualitative, quantitative and combined methods. Of the reviewed studies 123 were carried out by the qualitative data collection method while 84 studies gathered their data through the quantitative method. In addition, the results of this study show that the use of a combination of both research methods was not preferred by most researchers in recent years.

Another result of this study is that the flipped classroom approach has been applied to 18 different subject areas between 2010 and 2015. Although the application of the 
flipped classroom is a recent development, it is apparent that the flipped classroom model is adaptable for diverse subjects. Medical education is the most popular subject area for the implementation of the flipped classroom. The reason for this could be explained by the fact that medical students have focused more on practical lessons and the instructors who implemented the flipped classroom approach aimed to modify the learning environment by creating courses that included direct teaching and clinical components.

According to the results, the most preferred research model on flipped classroom applications was the experimental study. In addition, the case study model is secondly most preferred research model. From these results we conclude that the flipped classroom approach can be considered affective and applicable to very many contexts.

As experimental and case study models were popular, researchers preferred to gather data mostly by achievement tests such as quizzes, exams etc. as well as surveys. Furthermore, while the number of qualitative studies was high, document analysis, interviews and also other qualitative alternative data collection tools were used by a significant number of studies. On the other hand, the least preferred data collection tools were questionnaires and observation. Observation of learners would be difficult while they were watching course videos in their own homes.

Presentation of the article: February 13, 2017

Date of approval: March 11, 2017

Date of publication: Juny 30, 2017

Uzunboylu, H., y Karagözlü, D. (2017). The Emerging Trend of the Flipped Classroom: A Content Analysis of Published Articles between 2010 and 2015. RED. Revista de Educación a Distancia, 54. Consultado el (dd/mm/aaaa) en http://www.um.es/ead/red/54/uzunboylu_karagozlu.pdf

\section{Funding}

This research has received no funds from the public, commercial or non-profit funding agencies or bodies.

\section{References}

Avci, Y. ,Z., Vasu, E.S., Oliver, K., Keene, K.A., Fusarelli, B. (2014). Utilization of online technologies in mathematical problem solving at high school level: student and teacher perceptions. World Journal on Educational Technology. 6(2), 203217. 
Baepler, P., Walker, J., \& Driessen, M. (2014). It's not about seat time: Blending, flipping, and efficiency in active learning classrooms. Computers \& Education, 78, 227-236. doi:10.1016/j.compedu.2014.06.006 .

Barker, K., Omoni, G., Wakasiaka, S., Watiti, J., Mathai, M., \& Lavender, T. (2013). 'Moving with the times' taking a local approach: A qualitative study of African student nurse views of e learning. Nurse Education Today, 33(4), 407-412.

Bergmann, J., \& Sams, A. (2012). Flip your classroom: Reach every student in every class every day. Internal Society for Technology in Education.

Bergmann, J., Overmyer, J., \& Wilie, B. (2015). The Flipped Class: Myths vs. Reality THE DAILY RIFF - Be Smarter. About Education. Thedailyriff.com. Retrieved 5 January 2015, from http://www.thedailyriff.com/articles/the-flipped-classconversation-689.php

Butt, A. (2014). Student Views on the Use of a Flipped Classroom Approach: Evidence from Australia. Business Education \& Accreditation, 6(1), 33-43.

Chen, Y., Wang, Y., Kinshuk, \& Chen, N. (2014). Is FLIP enough? Or should we use the FLIPPED model instead? Computers \& Education, 79, 16-27. Doi:10.1016/j.compedu.2014.07.004.

Drysdale, J., Graham, C., Spring, K., \& Halverson, L. (2013). An analysis of research trends in dissertations and theses studying blended learning. The Internet and Higher Education, 17, 90-100. doi:10.1016/j.iheduc.2012.11.003.

Gilboy, M., Heinerichs, S., \& Pazzaglia, G. (2015). Enhancing Student Engagement Using the Flipped Classroom. Journal Of Nutrition Education And Behavior, 47(1), 109-114. doi:10.1016/j.jneb.2014.08.008

Hamdan, N., McKnight, P., McKnight, K., \& Arfstrom, K. (2013). Research, Reports \& Studies / Lit Review. Flippedlearning.org. Retrieved 5 January 2015, from http://www.flippedlearning.org/review

Hung, H. (2015). Flipping the classroom for English language learners to foster active learning. Computer Assisted Language Learning, 28(1), 81-96. doi:10.1080/09588221.2014.967701

Keser, H., Uzunboylu, H., \& Ozdaml1, F. (2011). The trends in technology supported collaborative learning studies in 21st century. World Journal On Educational Technology, 3(2), 103-119.

Kim, M., Kim, S., Khera, O., \& Getman, J. (2014). The experience of three flipped classrooms in an urban university: an exploration of design principles. The Internet and Higher Education, 22, 37-50. doi:10.1016/j.iheduc.2014.04.003

Lage, M., \& Platt, G. (2000). The Internet and the Inverted Classroom. The Journal of Economic Education, 31(1), 11-11. doi:10.1080/00220480009596756

Love, B., Hodge, A., Grandgenett, N., \& Swift, A. (2014). Student learning and perceptions in a flipped linear algebra course. International Journal of Mathematical Education in Science and Technology, 45(3), 317-324. doi:10.1080/0020739x.2013.822582 
Mate, K., \& Salinas, G. (2014). Flipping primary health care: A personal story. Healthcare, 2(4), 280-283. doi:10.1016/j.hjdsi.2014.10.003

McLaughlin, J., \& Rhoney, D. (2015). Comparison of an interactive e-learning preparatory tool and a conventional downloadable handout used within a flipped neurologic pharmacotherapy lecture. Currents in Pharmacy Teaching and Learning, 7(1), 12-19. doi:10.1016/j.cptl.2014.09.016

Novak, G.M. (2011). Just-in-time teaching. New Directions for Teaching and Learning, 2011(128), 63_73.

O'Flaherty, J., \& Phillips, C. (2015). The use of flipped classrooms in higher education: A scoping review. The Internet And Higher Education, 25, 85-95. doi:10.1016/j.iheduc.2015.02.002.

Ozcinar, Z. (2009). The topic of instructional design in research journals: A citation analysis for the years 1980-2008. Australasian Journal of Educational Technology, 25(4), 559-580.

Ozdamli, F. \& Tavukcu, T. (2016). Determination Of Secondary School Students' Attitudes Towards Tablet PC Supported Education. Journal of Universal Computer Science, 22, 4-15.

Ozdamli, F. \& Asiksoy, G. (2016). Flipped Classroom Adapted to ARCS Motivation Model on a Physics Course. Eurasia Journal of Mathematics, Science and Technology Education, 12 (6), 1589-1603 (SSCI)

Roach, T. (2014). Student perceptions toward flipped learning: New methods to increase interaction and active learning in economics. International Review of Economics Education, 17, 74-84. doi:10.1016/j.iree.2014.08.003

See, S., \& Conry, J. (2014). Flip My Class! A faculty development demonstration of a flipped-classroom. Currents in Pharmacy Teaching and Learning, 6(4), 585-588. doi:10.1016/j.cptl.2014.03.003

Simpson, V., \& Richards, E. (2015). Flipping the classroom to teach population health: increasing the relevance, Nurse Education in Practice. doi: 10.1016/j.nepr.2014.12.001.

Staker, H., \& Horn, M. (2012). Classifying K-12 blended learning. Innosight Institute. 